\title{
Induction of Heat Tolerance in Maize through Exogenous Application of Salicylic Acid, Ascorbic Acid and Hydrogen Peroxide in a Field Study
}

Muhammad Mazhar Iqbal ${ }^{1 *}$, Ijaz Ahmad ${ }^{2}$, Shahzad Maqsood Ahmed Basra ${ }^{3}$, Abu Baker Ijaz ${ }^{4}$, Zahid Hassan Tarar ${ }^{5}$, Muhammad Ansar $^{6}, \mathrm{Umer}_{\text {Iqbal}}{ }^{7}$, Tayyaba Naz ${ }^{4}$, Bilquees Fatima ${ }^{8}$, Muhammad Akram$^{9}$, Allah Wasaya ${ }^{10}$, Asif Iqbal ${ }^{11}$, Shakeel Ahmed Anwar ${ }^{12}$, Khalid Saif Ullah Khan ${ }^{13}$, Azeem Khalid ${ }^{14}$, Asif Aziz $^{15}$ and Rashid Mehmood ${ }^{16}$

${ }^{1}$ Soil and Water Testing Laboratory, Ayub Agricultural Research Institute, Chiniot, Punjab, Pakistan; ${ }^{2}$ Soil Conservation Group of Agriculture Department, Ratti, Gujrat, Punjab, Pakistan; ${ }^{3}$ Department of Agronomy, University of Agriculture, Faisalabad, Pakistan; ${ }^{4}$ Institute of Soil and Environmental Sciences University of Agriculture, Faisalabad, Pakistan; ${ }^{5}$ Soil and Water Testing Laboratory, Ayub Agricultural Research Institute, Mandi Bahauddin, Punjab, Pakistan; ${ }^{\circ}$ Department of Agronomy, PMAS Arid Agriculture University Rawalpindi, Pakistan; ${ }^{7}$ Crop Diseases Research Institute, National Agricultural Research Centre, Islamabad, Pakistan; ${ }^{8}$ Institute of Horticultural Sciences, University of Agriculture Faisalabad, Pakistan; ${ }^{\circ}$ Department of Environmental Sciences, COMSATS, Institute of Information Technology, Vehari, Pakistan; ${ }^{10}$ Department of Agronomy, Bahauddin Zakarya University Sub-Campus Layyah, Pakistan; ${ }^{11}$ On Farm Water Management, 21-Davis Road Lahore, Pakistan; ${ }^{12}$ Pulses Research Institute, Faisalabad, Pakistan; ${ }^{13}$ Department of Soil Science and Soil and Water Conservation, PMAS Arid Agriculture University Rawalpindi, Pakistan; ${ }^{14}$ Department of Environmental Sciences, PMAS Arid Agriculture University Rawalpindi, Pakistan; ${ }^{15}$ Department of Entomology, PMAS Arid Agriculture University Rawalpindi. Arid Agriculture University, Rawalpindi, Pakistan; ${ }^{16}$ Department of Plant Breeding and Genetics, PMAS Arid Agriculture University Rawalpindi, Pakistan.

Abstract | Temperature is a very important factor that affects crop yield. Maize, a monoecious plant, is adversely affected by high temperature during anthesis. Asynchronous fertilization and pollen desiccation reduce maize yield by reducing grain number and their size. Spray of hydrogen peroxide $\left(\mathrm{H}_{2} \mathrm{O}_{2}\right)$, salicylic acid (SA) and ascorbic acid (AsA) may induce heat stress tolerance. Spray of SA, AsA, and $\mathrm{H}_{2} \mathrm{O}_{2}$ increased chlorophyll, relative water and nutrient contents, membrane stability index (MSI) and antioxidants activities in heat stress. Moreover, foliar application of chemicals during normal and late planting improved the grain yield by increasing both the grain number and size. Foliar spray of $\mathrm{SA}, \mathrm{AsA}$ and $\mathrm{H}_{2} \mathrm{O}_{2}$ may induce heat tolerance by improving antioxidant activities which stabilized membrane and maintaining relative water, chlorophyll and nutrient content in ear leaves of maize during heat stress.

Received | February 02, 2020; Accepted | June 23, 2020; Published | August 01, 2020

*Correspondence | Muhammad Mazhar Iqbal, Soil and Water Testing Laboratory, Ayub Agricultural Research Institute, Chiniot, Punjab, Pakistan; Email: mazhar1621@gmail.com

Citation | Iqbal, M.M., I. Ahmad, S.M.A. Basra, A.B. Ijaz, Z.H. Tarar, M. Ansar, U. Iqbal, T. Naz, B. Fatima, M. Akram, A. Wasaya, A. Iqbal, S.A. Anwar, K.S.U. Khan, A. Khalid, A. Aziz and R. Mehmood. 2020. Induction of heat tolerance in maize through exogenous application of salicylic acid, ascorbic acid and hydrogen peroxide in a field study. Pakistan Journal of Agricultural Research, 33(3): 585-593.

DOI | http://dx.doi.org/10.17582/journal.pjar/2020/33.3.585.593

Keywords | Heat tolerance, Maize, Growth, Physiology, Biochemistry, Salicylic acid, Ascorbic acid, Hydrogen Peroxide

\section{Introduction}

$\mathrm{M}$ aize (Zea mays L.) is an important cereal crop and cultivated under divergent climatic conditions of spring and summer seasons in Pakistan (Tariq et al., 2002). Being monoecious crop and very much sensitive to high temperatures (Ullah et al., 2020) which causes severe irreversible changes in 
the membranes which leading to destabilize them and leaked electrolytes (Ahmad et al., 2014). High temperature stress also decreases crop production by shortening the life cycle (Muchow et al., 1990), inducing pollen sterility (Mohammed and Tarpley, 2009), decreasing water content (Ahmad et al., 2014) and chlorophyll biosynthesis (Havaux, 1998). Ultimately, heat limits the photosynthetic capacity, light interception, carbon assimilation (Steven et al., 2002) and causes distinctive losses in yield (Rowhani et al., 2011). These yield losses may attribute to overproduction of reactive oxygen species (ROS) during respiration process that results from exposure to high temperature and its negative effects on many plant physiological processes (Sairam and Tyagi, 2004).

Plants have adopted different protecting mechanisms of both enzymatic as well non-enzymatic in nature which counteract oxidative damage of ROS (Sairam and Tyagi, 2004). The enzymes like catalase (CAT), peroxidase (POD) and superoxide dismutase (SOD) while antioxidants, phytohormones and osmoprotectants are non-enzymatic in characteristics (Ahmad et al., 2013, 2014; Gill and Tuteja, 2010) may mitigate heat-induced damage by upregulating various scavenging mechanisms, including enzymatic and non-enzymatic antioxidants which detoxify ROS (Foyer and Noctor, 2003).

Different Non-enzymatic chemicals including SA, AsA, and low concentrations of $\mathrm{H}_{2} \mathrm{O}_{2}$ may alleviate the adversities of both temperature extremes on growth of maize through induction of enzymatic reactions which protect chlorophyll contents and membrane stability (Ahmad et al., 2012, 2014). Similarly, $\mathrm{H}_{2} \mathrm{O}_{2}$ is also a signalling molecule and its exogenous application at low concentration may induces the cold and heat stress by enhancing antioxidant activities, stabilizing cell membrane and protecting photosynthetic pigments in maize and mustard (Kumar et al., 2010; Ahmad et al., 2013). While at $\mathrm{H}_{2} \mathrm{O}_{2}$ higher levels, it damage the cellular system (Sairam and Tyagi, 2004; Kathiresan et al., 2006).

Based on this hypothesis, the present research work was planned to explore the impact of foliar spray of SA, AsA and $\mathrm{H}_{2} \mathrm{O}_{2}$ at anthesis to induce high temperature tolerance in maize and the mechanisms of high temperature stress tolerance of these chemicals in spring planted maize in diverse conditions.

\section{Materials and Methods}

This experimental study was performed at the research farm area, University of Agriculture, Faisalabad to explore response of foliar spray of $\mathrm{SA}, \mathrm{AsA}$ and $\mathrm{H}_{2} \mathrm{O}_{2}$ on physiological, biochemical and agronomic attributes maize hybrid (Hi Sawn 9697) under divergent conditions of 22 February (normal planting; NP) and 15 March (late planting; LP). The research was carried out in split plot design, randomizing sowing dates in main plots while foliar applied chemicals at $20 \mathrm{mg}$ $\mathrm{L}^{-1}$ at anthesis in the subplots. The $4.2 \times 7.7 \mathrm{~m}$ net plot size was used. All crop production and protection practices were kept uniform throughout research span. After 60 days of crop growth, samples of ear leaves for different physiological and biochemical attributes were collected at tasselling while yield data were at harvesting.

For determination of relative water content (RWC), $0.5 \mathrm{~g}$ of fresh ear leaves (fresh weigh, FW) samples were rinsed in separate test tubes for each experimental unit until this attained turgidity and weighed through an electric balance (turgid weight, TW). The turgid leaf's samples were air-dried and oven-dried for $24 \mathrm{~h}$ at $80^{\circ} \mathrm{C}$ and then weighed (dry weight, DW). The RWC was calculated by formula following Reddy (2004).

$$
R W C(\%)=\frac{F W-D W}{T W-D W} \times 100
$$

To determine the membrane stability index (MSI), leaf's samples of $200 \mathrm{mg}$ of each experimental unit were collected and placed in 2 sets of test tubes having doubled-distilled water (Sairam, 1994). One lot of test tubes of each treatment were heated at $40^{\circ} \mathrm{C}$ for 30 minutes while other set were boiled in a water bath at $100^{\circ} \mathrm{C}$ for 10 minutes. The electrical conductivity (EC) of each sample was measured using conductivity bridge.

For the determination of chlorophyll a and $b(C h l$ $a$ and $C h l b$ ) content, $0.5-\mathrm{cm}$ segments of fresh ear leaf of each experimental unit were collected after 60 days of crop growth. These samples were extracted overnight via $80 \%$ acetone at $-10^{\circ} \mathrm{C}$. These extracted samples were centrifuged at $14000 \times g$ for 5 minutes and absorbance of each supernatant sample was observed at 663 and $645 \mathrm{~nm}$ wavelength through spectrophotometer (T60). The chlorophyll $a$ and $b$ were intended via subsequent formula as described by Iqbal et al. (2020). 
Chl a $\left(m g 100 L^{-1}\right)=0.999 A_{663}-0.0989 A_{645}$ $\operatorname{Chl~b}\left(\mathrm{mg} 100 \mathrm{~L}^{-1}\right)=-0.328 A_{663}-1.77 A_{645}$

To extract antioxidant enzymes, $0.5 \mathrm{~g}$ of fresh leaf sample from each experimental unit were collected in test tube containing $8 \mathrm{~mL}$ of refrigerated phosphate buffer of $7 \mathrm{pH}(1 \%$, w/v) polyvinyl pyrrolidone. Each sample was ground with a tissue grinder and $0.2 \mathrm{~g}$ quartz sand was also poured in each sample. The homogenates of each experimental unit were centrifuged at $15000 \times g$ for 20 minutes at $4^{\circ} \mathrm{C}$ and enzymatic activities were assayed by using supernatant.

The SOD was detected through inhibitition the photo-reduction of nitro blue tetrazolium (NBT) (Giannopolitis and Ries, 1977) while POD and CAT activities was measured by using the mode as described by Naz et al. (2019).

Data on yield and its attributes were recorded using standard procedures. Air temperature was recorded for 19 weeks starting from the planting date or under normal (22 February) and heat stress conditions (15 March) and the mean temperature after the week of sowing was calculated (Table 1 ).

The above collected data were computed through Fisher's Analysis of Variance (ANOVA) technique and treatment means were contrasted via Least Significance Difference (LSD) test (Steel et al., 1997).

\section{Results and Discussion}

\section{Air temperature during study}

Maximum day temperatures of $31.4^{\circ} \mathrm{C}, 36.1^{\circ} \mathrm{C}, 40.5^{\circ} \mathrm{C}$, and $41.6^{\circ} \mathrm{C}$ for maize sown on 22 February (normal planting, NP) and maximum day temperatures of $41.6^{\circ} \mathrm{C}, 37.2^{\circ} \mathrm{C}, 39.7^{\circ} \mathrm{C}$, and $34.1^{\circ} \mathrm{C}$ for maize sown on 15 March (late planting, LP) were recorded during weeks 8, 9, 10 and 11 after sowing. Similarly, relative humidity (RH) values of $38.7 \%, 24.1 \%, 16.3 \%$, and $15.0 \%$ for NP maize, and 15.9\%, 32.9\%, 31.7\%, and 43.7\% for LP maize were recorded during weeks 8, 9, 10, and 11 after sowing (Table 1).

Table 1: Meteorological data recorded of experimental site from sowing to harvesting.

\begin{tabular}{|c|c|c|c|c|c|c|c|c|c|c|}
\hline \multirow{2}{*}{$\begin{array}{l}\text { Weeks after } \\
\text { sowing }\end{array}$} & \multicolumn{2}{|c|}{ Maximum Temp. $\left({ }^{\circ} \mathrm{C}\right)$} & \multicolumn{4}{|c|}{ Minimum Temp. $\left({ }^{\circ} \mathrm{C}\right)$ Average $\operatorname{Temp}\left({ }^{\circ} \mathrm{C}\right)$} & \multicolumn{2}{|c|}{ Relative humidity (\%) } & \multicolumn{2}{|c|}{ Rainfall (mm) } \\
\hline & $22^{\text {nd }}$ Feb. & $15^{\text {th }}$ March & $22^{\text {nd }}$ Feb. & $15^{\text {th }}$ March & $22^{\text {nd }}$ Feb. & $15^{\text {th }}$ March & $22^{\text {nd }}$ Feb. & $15^{\text {th }}$ March & $22^{\text {nd }}$ Feb. & $15^{\text {th }}$ March \\
\hline 1 & 23.4 & 31.9 & 7.7 & 15.4 & 15.5 & 23.7 & 34.6 & 34.6 & 0.0 & 0.0 \\
\hline 2 & 28.9 & 31.9 & 12.2 & 15.3 & 20.6 & 23.6 & 43.1 & 35.1 & 0.0 & 0.0 \\
\hline 3 & 29.0 & 32.7 & 13.1 & 16.9 & 21.1 & 24.8 & 40.1 & 36.4 & 0.0 & 0.8 \\
\hline 4 & 31.9 & 27.4 & 15.4 & 16.4 & 23.7 & 21.9 & 34.6 & 50.3 & 0.0 & 0.3 \\
\hline 5 & 31.9 & 31.4 & 15.3 & 18.4 & 23.6 & 24.9 & 35.1 & 38.7 & 0.0 & 1.2 \\
\hline 6 & 32.7 & 36.1 & 16.9 & 20.6 & 24.8 & 28.4 & 36.4 & 24.1 & 0.8 & 0.0 \\
\hline 7 & 27.4 & 40.5 & 16.4 & 21.1 & 21.9 & 30.8 & 50.3 & 16.3 & 0.3 & 0.0 \\
\hline $8^{*}$ & 31.4 & 41.6 & 18.4 & 24.9 & 24.9 & 33.3 & 38.7 & 15.9 & 1.2 & 0.0 \\
\hline 9 & 36.1 & 37.2 & 20.6 & 22.6 & 28.4 & 28.2 & 24.1 & 32.9 & 0.0 & 1.8 \\
\hline 10 & 40.5 & 39.7 & 21.1 & 25.2 & 30.8 & 32.5 & 16.3 & 31.7 & 0.0 & 1.6 \\
\hline 11 & 41.6 & 34.1 & 24.9 & 22.4 & 33.3 & 28.3 & 15.9 & 43.7 & 0.0 & 7.3 \\
\hline 12 & 37.2 & 39.6 & 22.6 & 27.3 & 28.2 & 33.5 & 32.9 & 30.9 & 1.8 & 0.0 \\
\hline 13 & 39.7 & 39.1 & 25.2 & 28.4 & 32.5 & 33.7 & 31.7 & 44.1 & 1.6 & 1.9 \\
\hline 14 & 34.1 & 38.4 & 22.4 & 26.8 & 28.3 & 32.6 & 43.7 & 50.9 & 7.3 & 0.2 \\
\hline 15 & 39.6 & 37.0 & 27.3 & 26.9 & 33.5 & 31.9 & 30.9 & 53.6 & 0.0 & 2.7 \\
\hline 16 & 39.1 & 38.0 & 28.4 & 27.9 & 33.7 & 33.0 & 44.1 & 53.9 & 1.9 & 1.2 \\
\hline 17 & 38.4 & 37.4 & 26.8 & 28.4 & 32.6 & 32.9 & 50.9 & 54.4 & 0.2 & 2.6 \\
\hline 18 & 37.0 & 36.1 & 26.9 & 26.5 & 31.9 & 31.3 & 53.6 & 61.4 & 2.7 & 2.0 \\
\hline 19 & 38.0 & 31.9 & 27.9 & 15.4 & 33.0 & 23.7 & 53.9 & 34.6 & 1.2 & 0.0 \\
\hline
\end{tabular}

*: Highlighted indicate the high after 56 days and foliar spray at 58 days after sowing.

\section{Physiological and biochemical attributes}

The chlorophyll $a$ and $b$ contents were decreased with rise in temperature but application SA, AsA, and
$\mathrm{H}_{2} \mathrm{O}_{2}$ significantly improved NP and LP planting conditions (Tables 2 and 4). The higher $C b l a$ and $C h l$ $b$ were observed when AsA applied alone and when 
both $\mathrm{SA}$ and $\mathrm{H}_{2} \mathrm{O}_{2}$ were applied as the most prominent compounds during the NP and LP plantings, despite facing high temperatures of $31.6^{\circ} \mathrm{C}$ and $41.6^{\circ} \mathrm{C}$ during tasseling, respectively. Minimum $C b l a$ and $C b l b$ were detected in maize in controlled treatments under NP and LP dates (Table 4). The RWC was significantly increased with foliar applied $\mathrm{SA}, \mathrm{AsA}$, and $\mathrm{H}_{2} \mathrm{O}_{2}$ in both NP and LP maize (Table 4). The foliarly applied SA, $\mathrm{H}_{2} \mathrm{O}_{2}$ and AsA and improved the RWC by $4 \%$ in NP maize and by $7 \%, 6 \%$ and $6 \%$, respectively, in LP maize. Similarly, exogenous spray of SA, AsA or $\mathrm{H}_{2} \mathrm{O}_{2}$ improved MSI by $5 \%, 5 \%$, and $5 \%$, respectively, in NP crops, and by 6\%, 7\%, and 6\% in LP crops, respectively, compared with respective controls (Table 4). Similarly, high temperatures reduced SOD activity but exogenously applied SA, AsA or $\mathrm{H}_{2} \mathrm{O}_{2}$ improved SOD activity by $13 \%, 6 \%$ and $14 \%$ in NP maize and by $7 \%, 3 \%$ and $5 \%$ in LP maize (Tables 2 and 4 ). The $\mathrm{H}_{2} \mathrm{O}_{2}$ was more effective than SA or AsA during increased temperatures up to $41.6^{\circ} \mathrm{C}$. Likewise, high temperature reduced CAT activity but foliarly applied $\mathrm{SA}, \mathrm{AsA}$, or $\mathrm{H}_{2} \mathrm{O}_{2}$ improved these activities by $123 \%, 47 \%$ and $74 \%$ in NP maize and by $93 \%$, $42 \%$ and $73 \%$ in LP maize, respectively (Tables 2 and 4). Likewise, peroxidase (POD) were augmented with exogenously applied $\mathrm{SA}, \mathrm{AsA}$, or $\mathrm{H}_{2} \mathrm{O}_{2}$ at the rate of $19 \%, 11 \%$ and $12 \%$ in NP and $9 \%, 11 \%$, and $9 \%$ in LP maize, respectively (Tables 2 and 4). While heat stress reduced $\mathrm{POD}$ activities, spray of $\mathrm{SA}, \mathrm{AsA}$ or $\mathrm{H}_{2} \mathrm{O}_{2}$ improved them to a larger amount in NP than in LP maize (Tables 2 and 4).

\section{Yield and yield components}

The maize yield and its components decreased with an increase in the temperature, but foliarly applied SA, AsA, or $\mathrm{H}_{2} \mathrm{O}_{2}$ increased those (Tables 3 and 5). Foliar spray of $\mathrm{SA}, \mathrm{AsA}$, or $\mathrm{H}_{2} \mathrm{O}_{2}$ improved cobs per plant by $2 \%, 3 \%$, and $5 \%$ in NP and by $2 \%, 2 \%$, and $4 \%$ in LP maize, respectively (Tables 3 and 5). Moreover, the number of grains declined with rise in the air temperature during anthesis but foliarly applied SA, AsA, or $\mathrm{H}_{2} \mathrm{O}_{2}$ enlarged grains per cob by 13,13 and 15\% in NP and 8, 9 and 10\% in LP (TTables 3 and 5). Similarly, 100-grain weight was also significantly increased by $\mathrm{SA}$, AsA, or $\mathrm{H}_{2} \mathrm{O}_{2}$ application. Lighter grains were produced in LP plants than in NP plants, however foliarly applied $\mathrm{SA}, \mathrm{AsA}$, or $\mathrm{H}_{2} \mathrm{O}_{2}$ amplified grain size by 3, 4 and 1\% in NP and 5, 6 and $7 \%$ in LP, respectively (Tables 3 and 5). Similarly, grain yield was reduced with rise in temperature the greater grain yield of $4.99 \mathrm{Mg} \mathrm{ha}{ }^{-1}$ was produced in NP than
4.12 $\mathrm{Mg} \mathrm{ha}^{-1}$ in LP. The SA, AsA or $\mathrm{H}_{2} \mathrm{O}_{2}$ application increased yield by 5, 3 and 4\% in NP and 16, 24 and $14 \%$ in LP, respectively (Tables 3 and 5). Relatively better response of chemicals was observed in LP than $\mathrm{NP}$ was linked with raise in grain number in NP while higher 100-grain weight in LP.

In present study, lower chlorophyll $\mathrm{a}$ and $\mathrm{b}$ contents were observed in LP maize than in NP of maize but spray of $\mathrm{SA}, \mathrm{AsA}$ or $\mathrm{H}_{2} \mathrm{O}_{2}$ improved the chlorophyll content in both NP and LP maize (Table 4). The lessening in chlorophyll contents can be owing to greater deterioration of the photosynthetic apparatus by oxy-radicals produced during increased respiration in response to high temperatures in stressed LP than non-stressed conditions NP. A similar decrease in the chlorophyll content was observed previously in turf grass and heat stressed maize (Jiang and Huang, 2001; Robin et al., 2014). The exogenous application of SA, AsA, or $\mathrm{H}_{2} \mathrm{O}_{2}$, increased chlorophyll contents in both NP and LP in present study were results of increased antioxidants activities and stabilizing membranes in this study. These results were in consonance with the findings of He and Huang (2007) whom also reported that thermo-tolerance was improved with antioxidant defence systems under heat stress and Scandalios (1993) speculated that the intracellular membrane might be damaged by ROS production, which can break down pigment.

The relatively higher RWC and MSI in NP than LP was observed in this study indicated that high temperature may be due to damage membranous system in response to heat but $\mathrm{SA}, \mathrm{AsA}$ or $\mathrm{H}_{2} \mathrm{O}_{2}$ increase RWC and MSI in NP and LP (Table 4). This increase in RWC can be associated with protective influence of exogenous molecules on the cell membrane against destruction by ROS produced during high temperatures in reaction with unsaturated fatty acids in phospholipids, which cause cell membrane damage. DaCosta and Huang (2007) and Robin et al. (2014) also reported that stress induces oxidative damage to membranes, but exogenous application of SA, AsA, or $\mathrm{H}_{2} \mathrm{O}_{2}$ may protect against lipid peroxidation through strengthening the antioxidant defence system.

High temperatures decreased the SOD activity but foliar spray of $\mathrm{SA}$, AsA, or $\mathrm{H}_{2} \mathrm{O}_{2}$ improved SOD activity in NP and in LP in maize (Table 4).

The reduced SOD activity under heat stress conditions 
Table 2: Mean square values for ear leaf chlorophyll a (Chl a), b (Chl b), and relative water contents (RWC), membrane stability index (MSI), superoxide dismutase (SOD), catalase (CAT) and peroxidase (POD) activity.

\begin{tabular}{|c|c|c|c|c|c|c|c|c|}
\hline Source of variation & DF & $\begin{array}{l}\text { Chl a }(\mathrm{mg} \\
\left.100 \mathrm{~mL}^{-1}\right)\end{array}$ & $\begin{array}{l}\text { Chl b (mg } \\
\left.100 \mathrm{~mL}^{-1}\right)\end{array}$ & MSI (\%) & $\begin{array}{l}\text { RWC } \\
(\%)\end{array}$ & $\begin{array}{l}\text { SOD activity } \\
\text { (units } \mathbf{~ m}^{-1} \text { Pr.) }\end{array}$ & $\begin{array}{l}\text { CAT activity } \\
\text { (units } \mathrm{mg}^{-1} \text { Pr.) }\end{array}$ & $\begin{array}{l}\text { POD activity } \\
\text { (units } \mathrm{mg}^{-1} \text { Pr.) }\end{array}$ \\
\hline Replication & 3 & $0.00004^{\mathrm{NS}}$ & $1.0084^{\mathrm{NS}}$ & $0.2599^{\mathrm{NS}}$ & $0.2599^{\mathrm{NS}}$ & $0.2056^{\mathrm{NS}}$ & $0.00181^{\mathrm{NS}}$ & $0.00068^{\mathrm{NS}}$ \\
\hline Sowing date & 1 & $6.02045^{* * *}$ & $11.2338^{*}$ & $5.78^{* *}$ & $7.78^{* *}$ & $11.2931^{* *}$ & $4.11845^{* *}$ & $0.03315^{* *}$ \\
\hline Error-I & 3 & 0.00001 & 2.0537 & 0.3344 & 0.3344 & 0.0161 & 0.00011 & 0.00001 \\
\hline Foliar spray & 3 & $0.09147^{\text {*** }}$ & $7.8^{*}$ & $26.5143^{* * *}$ & $26.5143^{* *}$ & $4.462^{* *}$ & $1.18749^{* *}$ & $0.01799^{* * *}$ \\
\hline Sowing date $\times$ Foliar spray & 18 & $0.08336^{* *}$ & $4.96^{*}$ & $0.7404^{* * *}$ & $0.7404^{* *}$ & $0.9762^{*}$ & $0.04861^{* *}$ & $0.00247^{\text {t** }}$ \\
\hline Error-II & 31 & 0.00005 & 0.4097 & 0.0615 & 0.0615 & 0.2565 & 0.00241 & 0.00001 \\
\hline
\end{tabular}

*: Significant at 0.05 p; **: bighly significant at 0.05 p; NS: Non Significant at 0.05 p.

Table 3: Mean square values for cobs per plant, grains per cob, 100-grain weight and grain yield.

$\begin{array}{llllll}\text { Source of variation } & \text { DF } & \text { Cobs per plants } & \text { Grains per cob } & \mathbf{1 0 0 - G r a i n ~ w e i g h t ~}(\mathbf{g}) & \text { Grain Yield }\left(\mathbf{M g ~ h a}^{-1}\right) \\ \text { Replication } & 3 & 0.00016^{\mathrm{NS}} & 4.3^{\mathrm{NS}} & 0.347^{\mathrm{NS}} & 0.02721^{\mathrm{NS}} \\ \text { Sowing Date } & 1 & 0.01051^{* *} & 77159.7^{* *} & 684.315^{* *} & 6.14251^{*} \\ \text { Error-I } & 3 & 0.00087 & 73.8 & 0.001 & 0.01595 \\ \text { Foliar Spray } & 3 & 0.00373^{*} & 4094.8^{* *} & 1.498^{*} & 0.38562^{* *} \\ \text { Sowing Date } \times \text { Foliar spray } & 18 & 0.00014^{\mathrm{NS}} & 362.8^{* *} & 1.379^{*} & 0.18302^{*} \\ \text { Error-II } & 31 & 0.001 & 42.6 & 0.161 & 0.03317\end{array}$

*: Significant at 0.05 p, **: highly significant at 0.05 p; NS: Non-Significant at 0.05 p.

Table 4: Comparison of chlorophyll a (Chl $a), b(C h l b)$ and membrane stability index (MSI), relative water contents $(R W C)$, superoxide dismutase (SOD), catalase (CAT) and peroxidase (POD) activity of spring sown maize as influenced by foliar application of ascorbic acid $(A s A)$, salicylic acid $(S A)$ and hydrogen peroxide $\left(\mathrm{H}_{2} \mathrm{O}_{2}\right)$ when planted on $22^{\text {nd }} \mathrm{Feb}$. and $15^{\text {th }}$ March.

\begin{tabular}{|c|c|c|c|c|c|c|c|c|}
\hline \multicolumn{2}{|c|}{ Treatments } & $\begin{array}{l}\text { Chl a (mg } \\
\left.100 \mathrm{~mL}^{-1}\right)\end{array}$ & $\begin{array}{l}\text { Chl b (mg } \\
\left.100 \mathrm{~mL}^{-1}\right)\end{array}$ & $\begin{array}{l}\text { Membrane sta- } \\
\text { bility index (\%) }\end{array}$ & $\begin{array}{l}\text { Relative water } \\
\text { contents (\%) }\end{array}$ & $\begin{array}{l}\text { SOD activity } \\
\text { (units } \mathrm{mg}^{-1} \text { Pr.) }\end{array}$ & $\begin{array}{l}\text { CAT activity } \\
\text { (units } \mathrm{mg}^{-1} \text { Pr.) }\end{array}$ & $\begin{array}{l}\text { POD activity } \\
\text { (units } \mathrm{mg}^{-1} \text { Pr.) }\end{array}$ \\
\hline \multicolumn{2}{|c|}{ 22nd Feb.(NP) } & $2.62 \mathrm{a}$ & 2.56 & $61.50 \mathrm{a}$ & $73.50 \mathrm{a}$ & $15.25 \mathrm{a}$ & $1.72 \mathrm{a}$ & $0.87 \mathrm{a}$ \\
\hline \multicolumn{2}{|c|}{ 15th March (LP) } & $1.75 \mathrm{~b}$ & 1.38 & $60.65 \mathrm{~b}$ & $72.65 b$ & $14.06 \mathrm{~b}$ & $0.99 \mathrm{~b}$ & $0.81 \mathrm{~b}$ \\
\hline \multicolumn{2}{|l|}{ LSD } & 0.003 & NS & 0.65 & 0.651 & 0.143 & 0.012 & 0.004 \\
\hline \multicolumn{2}{|l|}{ Control } & $2.19 \mathrm{c}$ & $1.50 \mathrm{~b}$ & $58.35 \mathrm{c}$ & $70.35 \mathrm{c}$ & $13.74 \mathrm{c}$ & $0.88 \mathrm{~d}$ & $0.77 \mathrm{c}$ \\
\hline \multicolumn{2}{|l|}{ AsA } & $2.04 \mathrm{~d}$ & $1.68 \mathrm{~b}$ & $61.87 \mathrm{~b}$ & $73.87 \mathrm{~b}$ & $14.40 \mathrm{~b}$ & $1.26 \mathrm{c}$ & $0.86 \mathrm{~b}$ \\
\hline \multicolumn{2}{|l|}{ SA } & $2.30 \mathrm{a}$ & $2.90 \mathrm{a}$ & $62.17 \mathrm{a}$ & $74.17 \mathrm{a}$ & $15.43 \mathrm{a}$ & $1.78 \mathrm{a}$ & $0.88 \mathrm{a}$ \\
\hline \multicolumn{2}{|l|}{$\mathrm{H}_{2} \mathrm{O}_{2}$} & $2.20 \mathrm{~b}$ & $1.79 \mathrm{~b}$ & $61.90 \mathrm{~b}$ & $73.90 \mathrm{~b}$ & $15.05 \mathrm{a}$ & $1.52 \mathrm{~b}$ & $0.86 \mathrm{~d}$ \\
\hline \multicolumn{2}{|l|}{ LSD } & 0.075 & 0.67 & 0.261 & 0.261 & 0.532 & 0.052 & 0.003 \\
\hline \multirow{4}{*}{$\begin{array}{l}\text { 22nd Feb } \\
\text { (NP). }\end{array}$} & Control & $2.41 \mathrm{~d}$ & $1.94 \mathrm{bc}$ & $59.21 \mathrm{~d}$ & $71.21 \mathrm{~d}$ & $13.94 \mathrm{~cd}$ & $1.13 \mathrm{e}$ & $0.81 \mathrm{f}$ \\
\hline & AsA & $2.75 \mathrm{~b}$ & $2.18 \mathrm{~b}$ & $62.21 \mathrm{abc}$ & $74.21 \mathrm{abc}$ & $14.79 \mathrm{~b}$ & $1.61 \mathrm{c}$ & $0.90 \mathrm{a}$ \\
\hline & SA & $2.79 \mathrm{a}$ & $4.21 \mathrm{a}$ & $62.32 \mathrm{a}$ & $74.32 \mathrm{a}$ & $16.36 \mathrm{a}$ & $2.18 \mathrm{a}$ & $0.88 \mathrm{c}$ \\
\hline & $\mathrm{H}_{2} \mathrm{O}_{2}$ & $2.52 \mathrm{c}$ & $1.92 \mathrm{bcd}$ & $62.24 \mathrm{ab}$ & $74.24 \mathrm{ab}$ & $15.90 \mathrm{a}$ & $1.95 \mathrm{~b}$ & $0.90 \mathrm{a}$ \\
\hline \multirow{4}{*}{$\begin{array}{l}\text { 15th } \\
\text { March } \\
\text { (LP) }\end{array}$} & Contro $_{1}$ & $1.65 \mathrm{~h}$ & $1.06 \mathrm{f}$ & $57.49 \mathrm{e}$ & $69.49 \mathrm{e}$ & $13.53 \mathrm{~d}$ & $0.62 \mathrm{~g}$ & $0.73 \mathrm{~g}$ \\
\hline & AsA & $1.68 \mathrm{~g}$ & $1.19 \mathrm{e}$ & $61.52 \mathrm{c}$ & $73.52 \mathrm{c}$ & $14.00 \mathrm{~cd}$ & $0.91 \mathrm{f}$ & $0.81 \mathrm{f}$ \\
\hline & $\mathrm{SA}$ & $1.82 \mathrm{f}$ & $1.59 \mathrm{de}$ & $62.02 \mathrm{abc}$ & $74.02 \mathrm{abc}$ & $14.50 \mathrm{bc}$ & $1.38 \mathrm{~d}$ & $0.87 \mathrm{~d}$ \\
\hline & $\mathrm{H}_{2} \mathrm{O}_{2}$ & $1.86 \mathrm{e}$ & $1.67 \mathrm{bcd}$ & $61.56 \mathrm{bc}$ & $73.56 \mathrm{bc}$ & $14.21 \mathrm{bcd}$ & $1.08 \mathrm{e}$ & $0.82 \mathrm{e}$ \\
\hline \multicolumn{2}{|l|}{ LSD } & 0.0106 & 0.45 & 0.368 & 0.175 & 0.752 & 0.073 & 0.004 \\
\hline
\end{tabular}

Means sharing same letter in a column do not differ significantly at 0.05 probability level.

might reflect higher $\mathrm{O}_{2}^{-}$production in heat stressed of $\mathrm{H}_{2} \mathrm{O}_{2}$ was more effective for maintaining SOD maize but exogenous application at low concentration activity under heat stress by detoxifying superoxide 
$\left(\mathrm{O}_{2}^{-}\right)$. Maximal SOD activities may require protection against superoxide which is reduced in the LP conditions, in this study leading to more severe heat damage to the leaves in this study (Table 4). Previously, plants must protect themselves from these oxidative injuries by maintaining sufficient levels of SOD were also reported by Scandalios (1993).

The most important scavenging enzyme in organisms is CAT, which detoxifies $\mathrm{H}_{2} \mathrm{O}_{2}$ into $\mathrm{O}_{2}^{-}$. In present research, the CAT and POD were observed in NP than LP but exogenous effectors molecules increased CAT and POD activities in this study was observed (Table 4). A reduction in CAT and POD activities at heat stress conditions was also reported in crop plants when exposed to heat stress (Dat et al., 1998; Foyer et al., 1997; Jiang and Huang, 2001; Sato et al., 2001). The essential role of CAT for scavenging $\mathrm{H}_{2} \mathrm{O}_{2}$ was established in chloroplasts, where CAT is absent (Asada and Takahashi, 1987). Although heat stress reduced POD activity, exogenous spray of SA, AsA, or $\mathrm{H}_{2} \mathrm{O}_{2}$ increased POD activity in both NP and LP maize. Moreover, these chemicals induced more POD activity in NP maize than in LP maize. The higher POD activity due to the application of $\mathrm{SA}, \mathrm{AsA}$, or $\mathrm{H}_{2} \mathrm{O}_{2}$ upon exposure to heat stress may be due to improved scavenging system, which protects the membranes from the deleterious effects of heat via converting superoxide radicals to $\mathrm{H}_{2} \mathrm{O}_{2}$ and $\mathrm{H}_{2} \mathrm{O}_{2}$ to $\mathrm{O}_{2}^{-}$. Higher POD might enhance the $\mathrm{H}_{2} \mathrm{O}_{2}$ scavenging system by exogenous or foliar application of stress signalling molecules like AsA, SA, or a low concentration of $\mathrm{H}_{2} \mathrm{O}_{2}$ may impair the accumulation of ROS of $\mathrm{H}_{2} \mathrm{O}_{2}$, resulted lower heat-induced injury. These findings demonstrate the dual role of $\mathrm{H}_{2} \mathrm{O}_{2}$ as a ROS and as a signalling molecule in induction of heat stress. A decline in POD under heat stress conditions was also reported by Almeselmani et al. (2006). The heat induced a reduction in POD activity in both $\mathrm{NP}$ and LP maize, suggesting that POD is sensitive to high temperatures and $\mathrm{SA}, \mathrm{SA}, \mathrm{H}_{2} \mathrm{O}_{2}$. In addition, antioxidant enzyme activity is increased by AsA, SA, and $\mathrm{H}_{2} \mathrm{O}_{2}$ application in different crops under stress. The current research results are also in line with Khan et al. (2006), Ahmad et al. (2013, 2014) and Appu and Muthukrisnan (2014) whom concluded that antioxidant activity is improved by foliarly applied SA, AsA, and $\mathrm{H}_{2} \mathrm{O}_{2}$ at suboptimal temperature in maize.

The higher grain yield, number of cobs and grains as well as 100-grain weight was produced in NP than
LP, but foliarly applied SA, AsA, or $\mathrm{H}_{2} \mathrm{O}_{2}$ enlarged under normal and stressful conditions of high temperature (Table 5) The grain yield is commutative effects of various yield attributes which started from pollen fertilization ended grain harvesting. The number of grains reduced in this study indicated that high may reduce pollen fertilization while poor grain development produce small grains size (Table 4). The reduction of grain yield owing to high temperature was pragmatic as a result lesser grains and poor grain number by Jones and Thornton (2003), Lobell et al. (2008), and Rowhani et al. (2011) who also reported lower as result of poor fertilization and grain development under heat stress. Application of exogenous effectors improved the physiological, biochemical, and yield attributes, ultimately resulting in increased maize grain yield even under high temperature (Table 5).

Table 5: Comparison of cobs per plant, grains per cob, 100-grain weight and grain yield of spring sown maize as influenced by foliar application of ascorbic acid, salicylic acid and bydrogen peroxide when planted on $22^{\text {nd }}$ Feb. and $15^{\text {th }}$ March.

\begin{tabular}{|c|c|c|c|c|c|}
\hline \multicolumn{2}{|c|}{ Treatments } & $\begin{array}{l}\text { Cobs per } \\
\text { Plant }\end{array}$ & $\begin{array}{l}\text { Grains } \\
\text { per cob }\end{array}$ & $\begin{array}{l}\text { 100-Grain } \\
\text { weight (g) }\end{array}$ & $\begin{array}{l}\text { Grain Yield } \\
\left(\mathrm{Mg} \mathrm{ha}^{-1}\right)\end{array}$ \\
\hline \multicolumn{2}{|c|}{$22^{\text {nd }} \mathrm{Feb}(\mathrm{NP})$} & $1.32 \mathrm{a}$ & $471.5 \mathrm{a}$ & $31.05 \mathrm{a}$ & $4.99 \mathrm{a}$ \\
\hline \multicolumn{2}{|c|}{$15^{\text {th }}$ March (LP) } & $1.29 \mathrm{~b}$ & $373.3 \mathrm{~b}$ & $21.80 \mathrm{~b}$ & $4.12 \mathrm{~b}$ \\
\hline \multicolumn{2}{|c|}{ LSD } & 0.033 & 9.67 & 0.033 & 0.142 \\
\hline \multicolumn{2}{|c|}{ Control } & $1.28 \mathrm{~b}$ & $388.8 \mathrm{c}$ & $26.40 \mathrm{~b}$ & $4.24 \mathrm{~b}$ \\
\hline \multicolumn{2}{|c|}{ AsA } & $1.31 \mathrm{ab}$ & $431.4 \mathrm{~b}$ & $26.88 \mathrm{a}$ & $4.75 \mathrm{a}$ \\
\hline \multicolumn{2}{|l|}{ SA } & $1.31 \mathrm{ab}$ & $430.7 \mathrm{~b}$ & $26.57 \mathrm{ab}$ & $4.65 \mathrm{a}$ \\
\hline \multicolumn{2}{|l|}{$\mathrm{H}_{2} \mathrm{O}_{2}$} & $1.33 \mathrm{a}$ & $438.5 \mathrm{a}$ & $25.85 \mathrm{c}$ & $4.58 \mathrm{a}$ \\
\hline \multicolumn{2}{|l|}{ LSD } & 0.033 & 6.85 & 0.421 & 0.191 \\
\hline \multirow{4}{*}{$\begin{array}{l}22^{\text {nd }} \\
\text { Feb } \\
\text { (NP). }\end{array}$} & Control & $1.29 \mathrm{bc}$ & $428.0 \mathrm{~b}$ & $30.43 \mathrm{c}$ & $4.85 \mathrm{a}$ \\
\hline & AsA & $1.33 \mathrm{ab}$ & $482.5 \mathrm{a}$ & $31.70 \mathrm{a}$ & $4.99 \mathrm{a}$ \\
\hline & SA & $1.32 \mathrm{ab}$ & $484.7 \mathrm{a}$ & $31.23 \mathrm{ab}$ & $5.10 \mathrm{a}$ \\
\hline & $\mathrm{H}_{2} \mathrm{O}_{2}$ & $1.35 \mathrm{a}$ & $490.7 \mathrm{a}$ & $30.83 \mathrm{bc}$ & $5.03 \mathrm{a}$ \\
\hline \multirow{4}{*}{$\begin{array}{l}\text { 15th } \\
\text { March } \\
\text { (LP) }\end{array}$} & Control & $1.26 \mathrm{c}$ & $349.7 \mathrm{~d}$ & $20.87 \mathrm{e}$ & $3.63 \mathrm{~d}$ \\
\hline & AsA & $1.29 \mathrm{bc}$ & $380.3 c$ & $22.07 \mathrm{~d}$ & $4.51 \mathrm{~b}$ \\
\hline & SA & $1.29 \mathrm{bc}$ & $376.7 \mathrm{c}$ & $21.90 \mathrm{~d}$ & $4.20 \mathrm{c}$ \\
\hline & $\mathrm{H}_{2} \mathrm{O}_{2}$ & $1.31 \mathrm{ab}$ & $386.3 c$ & $22.37 \mathrm{~d}$ & $4.13 \mathrm{c}$ \\
\hline \multicolumn{2}{|l|}{ LSD } & 0.047 & 9.692 & 0.596 & 0.271 \\
\hline
\end{tabular}

Means sharing same letter in a column do not differ significantly at 0.05 probability level.

The results depicted that number of grains declined with rise temperature during anthesis, which might be due to pollen desiccation and failed fertilisation, but exogenous application of $\mathrm{SA}, \mathrm{AsA}$, or $\mathrm{H}_{2} \mathrm{O}_{2}$ increased 
grains per cob by ameliorating the adversities of high temperature $\left(31.6^{\circ} \mathrm{C}\right.$ and $\left.41.6^{\circ} \mathrm{C}\right)$ on grains (Table 5). High temperature adversely affects grain number by increased pollen abortion, poor fertilization (Dupuis and Dumas, 1990; Talwar et al., 1999) and desiccating exposed pollen grains (Sinsawat et al., 2004), while $\mathrm{SA}, \mathrm{AsA}$ or $\mathrm{H}_{2} \mathrm{O}_{2}$ application reduced these effects in both NP and LP maize exposed to an ambient temperature of $31.4^{\circ} \mathrm{C}$ (normal) or heat stressed $\left(41.6^{\circ} \mathrm{C}\right)$ under late sown conditions during tasseling (8 weeks after sowing).

Lighter grains were produced in LP maize than in NP maize, but foliarly applied SA, AsA, or $\mathrm{H}_{2} \mathrm{O}_{2}$ increased grain size regardless of the planting date. Lighter grain during late planting when plants face high temperatures during anthesis and grain formation stage may be due to the adversities of heat stress on kernel development. Drastic impacts of high temperature on grain development owing to asynchronous fertilization and grain formation were also reported by Rahman et al. (2013). Comparable destructive influences of high temperature on grain development were quoted by Gibson and Paulsen (1999), Rahman et al. (2013) and Viswanathan and Chopra (2001).

\section{Conclusions and Recommendations}

In present study, foliar spray of $\mathrm{SA}, \mathrm{AsA}$, or $\mathrm{H}_{2} \mathrm{O}_{2}$ induced high temperature stress tolerance in maize by improving growth through protecting chlorophyll, increasing water and nutrient uptake, antioxidants activities and stabilising cell membranes These positive changes eventually resulted in increased maize yield by improving grain number and size under heat stress. Induction of these positive changes in the photosynthetic pigments and stabilisation of membranes through applied $\mathrm{AsA}, \mathrm{SA}$ or $\mathrm{H}_{2} \mathrm{O}_{2}$, which exhibited differential responses in NP and LP maize exposed to heat stress, may lead to improvement in heat stress tolerance.

\section{Author's Contribution}

Muhammad Mazhar Iqbal has written the main body of present manuscript. Ijaz Ahmad conducted and carried out the present research study. Shahzad Masood Ahmed Basra designed and supervised the present research. Abu Bakar Ijaz helped in literature citation and references. Zahid Hassan Tarar has contributed in data collection and laboratory analysis. Muhammad Ansar critically reviewed and edited the manuscript. Umer Iqbal has has helped in data collection and determination of different parameters in laboratory. Tayyaba $\mathrm{Naz}$ statistically analyzed the obtained data. Bilquees Fatima has significantly contributed in Discussion. Muhammad Akram considerably contributed in Introduction. Allah Wasaya facilitated in Materials and Methods. Asif Iqbal noticeably assisted in Results. Shakeel Ahmed Anwar helped in research experimentation, availability of inputs and data tabulation. Khalid Saif Ullah Khan and Azeem Khalid critically read and improved the manuscript for publication in Pakistan Journal of Agricultural Research. Asif Aziz helped in maize crop protection measures. Rashid Mehmood helped in agronomic production system of maize crop.

\section{Acknowledgements}

The authors are also thankful to Higher Education Commission, Islamabad for providing funds for this research study.

\section{Conflict of interest}

The authors declare that they have no conflict of interest.

\section{References}

Ahmad, I., S.M.A. Basra, I. Afzal, M. Farooq and A. Wahid. 2013. Growth improvement in spring maize through exogenous application of ascorbic acid, salicylic acid and hydrogen peroxide. Int. J. Agric. Biol. 15: 95-100.

Ahmad, I., S.M.A. Basra and A. Wahid. 2014. Exogenous application of ascorbic acid, salicylic acid and hydrogen peroxide improves the productivity of hybrid maize under at low temperature stress. Int. J. Agric. Biol. 16: 825830.

Ahmad, I., T. Khaliq, A. Ahmad, S.M.A. Basra, Z. Hussain and A.Ali.2012.Effect of seed priming with ascorbic acid, salicylic acid and hydrogen peroxide on emergence, vigor and antioxidant activities of maize. Afr. J. Biotech. 11: 11271132. https://doi.org/10.5897/AJB11.2266

Ahmad, I., S.M.A. Basra, S. Hussain, S.A. Hussain, Hafeez-ur-Rehman, A. Rehman and A. Ali. 2015. Priming with ascorbic acid, salicylic acid and hydrogen peroxide improves seedling 
growth of spring. J. Environ. Agric. Sci. 3:14-22.

Almeselmani, M., P.S. Deshmukh, R.K. Sairam,

S.R. Kushwaha and T.P. Singh. 2006. Protective role of antioxidant enzymes under high temperature stress. Plant Sci. 171: 382-388. https://doi.org/10.1016/j.plantsci.2006.04.009

Appu, M. and S. Muthukrishnan. 2014. Foliar application of salicylic acid stimulates flowering and induce defense related proteins in finger millet plants. Universal J. Plant Sci. 2: 14-18.

Asada, K. and M. Takahashi. 1987. Production and scavenging of active oxygen in photosynthesis. in Photoinhibition: Topics of Photosynthesis, DJ Kyle, CB Osmond and CJ Arntzen, Eds, Elsevier, Amsterdam, $9^{\text {th }}$ edition, The Netherlands. pp. 227-287.

Chance, M. and A.C. Maehly. 1955. Assay of catalases and peroxidases. Methods Enzymol. 2: 764-775. https://doi.org/10.1016/S00766879(55)02300-8

DaCosta, M. and B. Huang 2007. Changes in antioxidant enzyme activities and lipid peroxidation for bent grass species in response to drought stress. J. Am. Soc. Hort. Sci. 132: 417-422. https://doi.org/10.21273/ JASHS.132.3.319

Dat, J.F., H. Lopez-Dalgado, C.H. Foyer and I.M. Scott. 1998. Parallel changes in $\mathrm{H}_{2} \mathrm{O}_{2}$ and catalase during thermotolerance induced by salicylic acid or heat acclimation in mustard seedlings. Plant Physiol. 116: 1351-1357. https://doi.org/10.1104/pp.116.4.1351

Dupuis, I. and Dumas, C. 1990. Influence of temperature stress on maize (in vitro) fertilization and heat shock protein synthesis in maize (Zea mays L.) reproductive tissue. Plant Physiol. 94: 665-670. https://doi.org/10.1104/ pp.94.2.665

Foyer, C.H., H. Lopez-Delgado, J.F. Dat and I.M. Scott. 1997. Hydrogen peroxide- and glutathione-associated mechanisms of acclamatory stress tolerance and signaling. Physiol. Plant. 100: 241-254. https://doi. org/10.1034/j.1399-3054.1997.1000205.x

Foyer, C.H. and G. Noctor. 2003. Redox sensing and signaling associated with reactive oxygen in chloroplasts, peroxisomes and mitochondria. Physiol. Plant. 119: 355-364. https://doi. org/10.1034/j.1399-3054.2003.00223.x

Giannopolitis, C.N. and S.K.Ries.1977. Superoxide dismutase. I. Occurrence in higher plants. Plant
Physiol. 59: 309-314. https://doi.org/10.1104/ pp.59.2.309

Gibson, L.R. and G.M. Paulsen. 1999. Yield components of wheat grown under high temperature stress during reproductive growth. Crop Sci. 39: 1841-1846. https://doi. org/10.2135/cropsci1999.3961841x

Gill, S.S. and N. Tuteja. 2010. Reactive oxygen species and antioxidant machinery in abiotic stress tolerance in crop plants. Plant Physiol. Biochem. 48: 909-930. https://doi. org/10.1016/j.plaphy.2010.08.016

Havaux, M., 1998. Carotenoids as membrane stabilizers in chloroplasts. Trends Plant Sci. 3: 147-151. https://doi.org/10.1016/S13601385(98)01200-X

He, Y. and B. Huang. 2007. Protein changes during heat stress in three kentucky bluegrass cultivars differing in heat tolerance. Crop Sci. 47: 2513-2520. https://doi.org/10.2135/ cropsci2006.12.0821

Iqbal, M.M., T. Naz, M.I. Zafar, M. Imtiaz, O. Farooq, A. Rehman, S. Ali, M. Rizwan, S. Hussain, W. Javed, G. Murtaza, M. Afzal, A. Mahmood, S.M. Mehdi, M.A. Sarwar and G. Du Laing. 2020. Green remediation of salinesodic $\mathrm{Pb}$-factored soil by growing salt-tolerant rice cultivar along with soil applied inorganic amendments. Paddy Water Environ. https:// doi.org/10.1007/s10333-020-00807-6

Jiang, Y. and B. Huang. 2001. Effects of calcium on antioxidant activities and water relations associated with heat tolerance in two coolseason grasses. J. Exp. Bot. 52: 341-349. https:// doi.org/10.1093/jexbot/52.355.341

Jones, P.G. and P.K. Thornton. 2003. The potential impacts of climate change on maize production in Africa and Latin America in 2055. Glob. Environ. Change. 13: 51-59. https://doi. org/10.1016/S0959-3780(02)00090-0

Kathiresan, A., H.R. Lafitte, J. Chen, L. Mansueto, R. Bruskiewich and J. Bennett. 2006. Gene expression microarrays and their application in drought stress research. Field Crops Res. 97: 101-110. https://doi.org/10.1016/j. fcr.2005.08.021

Khan, A., M. Sajid, A. Ahmad, H.R. Athar and M. Ashraf. 2006. Interactive effect of foliarly applied ascorbic acid and salt stress on wheat (Triticum aestivum L.) at the seedling stage. Pak. J. Bot. 38: 1407-1414. 
Kumar, M., G. Sirhindi, R. Bhardwaj, S. Kumar and G. Jain. 2010. Effect of exogenous $\mathrm{H} 2 \mathrm{O} 2$ on antioxidant enzymes of Brassica juncea $\mathrm{L}$. seedlings in relation to 24-epibrassinolide under chilling stress. Indian J. Biochem. Biophys. 47:378-382.

Lobell, D.B., M.B. Burke, C. Tebaldi, M.D. Mastrandrea, W.P. Falcon and R.L. Naylor. 2008. Prioritizing climate change adaptation and needs for food security in 2030. Science. 319: 607-610. https://doi.org/10.1126/ science.1152339

Mohammed, A.R. and L. Tarpley. 2009. High nighttime temperatures affect rice productivity through altered pollen germination and spikelet fertility. Agric. For. Meteorol. 149: 999-1008. https://doi.org/10.1016/j. agrformet.2008.12.003

Muchow, R.C., T.R. Sinclair and J.M. Bennett. 1990. Temperature and solar radiation effects on potential maize yield across locations. Agron. J. 82: 338-343. https://doi.org/10.2134/agronj19 $90.00021962008200020033 x$

Naz, T., J. Akhtar, M.M. Iqbal, M. Anwar-ul-Haq, G. Murtaza, N.K. Niazi, Atique-ur-Rehman, O. Farooq, M. Ali and B. Dell, 2019. Assessment of gas exchange attributes, chlorophyll contents, ionic composition and antioxidant enzymes of bread wheat genotypes in boron toxic, saline and boron toxic-saline soils. Int. J. Agric. Biol. 21: 1271-1278.

Rahman, S., M. Arif, K. Hussain, S. Hussain, T. Mukhtar, A. Razaq and R.A. Iqbal. 2013. Evaluation of maize hybrids for tolerance to high temperature stress in Central Punjab. Am. J. Bioengr. Biotechnol. 1: 30-36. https://doi. org/10.7726/ajbebt.2013.1003

Reddy, S.R. 2004. Principles of Crop Production. $2^{\text {nd }}$ Ed. Kalyani Publishers, New Dehli, India, pp. 354.

Robin, A.W., M.K. Sangha, S.S. Banga, A.K. Atwal and S. Gupta. 2014. Heat stress tolerance in relation to oxidative stress and antioxidants in Brassica juncea. J. Environ. Biol. 35: 383-387.

Rowhani, P., D.B. Lobell, M. Linderman and N. Ramankutty. 2011. Climate variability and crop production in Tanzania. Agric. Forest Meteorol. 151: 449-460. https://doi.org/10.1016/j. agrformet.2010.12.002

Sairam, R.K., 1994. Effect of moisture stress on physiological activities of two contrasting wheat genotypes. Indian J. Exp. Biol. 32: 594-597.

Sairam, R.K. and A. Tyagi. 2004. Physiological and molecular biology of salinity stress tolerance in plants. Curr. Sci. 86: 407-421.

Sato, Y., T. Murakami, H. Funatsuki, S. Matsuba, H. Saruyama and M. Tanida. 2001. Heat shockmediated APX gene expression and protection against chilling injury in rice seedlings. J. Exp. Bot. 52: 145-151. https://doi.org/10.1093/ jexbot/52.354.145

Scandalios,J.G.,1993. Oxygen stress and superoxide dismutases. Plant Physiol. 101: 7-12. https:// doi.org/10.1104/pp.101.1.7

Sinsawat, V., J. Pandy, P. Leipner, P. Stamp and Y. Fracheboud. 2004. Effect of heat stress on the Photosynthetic apparatus in maize (Zea mays L.) grown at control and high temperature. Environ. Exp. Bot. 52: 123-129. https://doi. org/10.1016/j.envexpbot.2004.01.010

Steel, R.G.D., T.H. Torrie and D.A. Dickey. 1997. Principles and procedures of statistics. A Biometrical Approach $3^{\text {rd }}$ Ed. McGraw Hill Book International Co. Inc., Singapore, pp. 204-232.

Steven, J., C. Brandner and M. Salvucci. 2002. Sensitivity of photosynthesis in C4 maize plant to heat stress. Plant Physiol. 129: 1773-1780. https://doi.org/10.1104/pp.002170

Talwar, H.S., H. Takeda, S. Yashima and T. Senboku. 1999. Growth and photosynthetic responses of groundnut genotypes to high temperature. Crop Sci.39: 460-466. https://doi.org/10.2135/ cropsci1999.0011183X0039000200027x

Tariq, M., M.A. Khan and S. Parveen. 2002. Response of maize to applied soil Zinc. Asian J. Plant Sci. 1:476-477. https://doi.org/10.3923/ ajps.2002.476.477

Ullah, N., A. Ditta, A. Khalid, S. Mehmood, M.S. Rizwan, M. Ashraf, F. Mubeen, M. Imtiaz and M.M. Iqbal. 2020. Integrated effect of algal biochar and plant growth promoting rhizobacteria on physiology and growth of maize under water deficit irrigations. J. Soil Sci. Plant Nutr. 20: 346-356. https://doi. org/10.1007/s42729-019-00112-0

Viswanathan, C. and R.K. Chopra. 2001. Effect of heat stress on grain growth, starch synthesis and protein synthesis in grains of wheat varieties differing in grain weight stability.J. Agron. Crop Sci. 186: 1-7. https://doi.org/10.1046/j.1439037x.2001.00432.x 